\title{
Pengaruh Model Pembelajaran Kooperatif Tipe Team Game Tournament Berbantu Media Ledusa Tema 3
}

\author{
Ayu Parmawati ${ }^{1}$, Fine Reffiane ${ }^{2}$, Husnul $\mathrm{Hadi}^{3}$ \\ Universitas PGRI Semarang \\ e-mail: ayu.upgri@upgris.ac.id
}

\begin{abstract}
Abstrak
Penelitian ini bertujuan mengetahui pengaruh model pembelajaran kooperatif tipe team game tournament berbantu media ledusa terhadap hasil belajar, kepanjangan ledusa adalah lempar dadu raksasa. Populasi pada penelitian ini adalah seluruh siswa kelas IV SDN Kembangsari 01 Semarang, Karena pada penelitian ini jumlah populasinya kurang dari 100 siswa, maka jumlah sampel sama dengan jumlah populasi sebanyak 24 siswa. Penelitian ini hanya menggunakan satu kelas saja dimana penelitian ini dapat menguji pengaruh model kooperatif tipe TGT berbantu media ledusa, dengan membandingkan hasil siswa sebelum diberi perlakuan dan sesudah diberi perlakuan. Sebelum diberi perlakuan rata-rata nilai siswa dengan uji normalitas adalah 71,67 , setelah diber perlakuan nilai rata-rata siswa menjadi 81,87 . Model pembelajaran kooperatif tipe TGT memperoleh tanggapan positif yaitu siswa merasa senang dan tidak membosankan dengan pembelajaran team game tournament berbantu media ledusa dan dapat meningkatkan pemahaman pada tema 3 peduli terhadap makhluk hidup kelas VI. Simpulan dari penelitian ini yaitu model pembelajaran kooperatif tipe team game tournament berbantu media ledusa kelas VI SDN Kembangsari 01 Semarang berpengaruh signifikan terhadap hasil belajar pada tema 3 peduli terhadap makhluk hidup kelas VI dan mendapat tanggapan positif dari siswa. Parmawati, A. 2019. Pengaruh Model Kooperatif Tipe Team game tournament berbantu media ledusa kelas VI SDN Kembangsari 01 Semarang.
\end{abstract}

Kata Kunci: Model team game tournament, media ledusa, hasil belajar tema 3

\begin{abstract}
This study aims to determine the effect of the learning model cooperative type ledusa media assisted game tournament team to learning result; the elbow length is throwing giant dice. Population in this study was all fourth grade students of SDN Kembangsari 01 Semarang, population was less than 100 students, the number of samples equal to the total population of 24 students. This research use only one class where this study can test the influence of Cooperative type TGT models supported by solar media, by comparing the results before being treated and after being treated. Before being given, the average treatment of students with normality test was 71.67, after being given treatment, the value was 81.87 . Cooperative learning model TGT receives a positive response; students feel happy and not boring with team learning media-assisted tournament games ledusa and can improve understanding of the theme 3 care about living class VI. The conclusion of this study is the learning model type of team tournament game assisted by media in the sixth grade of SDN Kembangsari 01 Semarang has a significant effect on learning outcomes at theme 3 cares about living beings in class VI and gets a positive response from students. Parmawati, A. 2019. The effect of Cooperative Model TGT type mediaassisted tournament led by class VI at SDN Kembangsari 01 Semarang
\end{abstract}

Keywords: Team game tournament model, ledusa media, theme 3 


\section{Pendahuluan}

Pendidikan adalah pondasi kehidupan suatu bangsa, semakin maju pendidikan maka semakin terarah kesejahteraan masyarakat bangsa tersebut. Stategi pembelajaran dalam hal ini adalah penguasaan guru mengenai model, metode serta media pembelajaran. Seiring perkembangan teknologi, banyak sekali model, metode, dan media pembelajaran yang semakin berkembang.

Pendidikan juga merupakan hal terpenting bagi setiap negara untuk dapat berkembang pesat. Negara yang hebat akan menempatkan pendidikan sebagai prioritas pertamanya, karena dengan pendidikan, kemiskinan pada rakyat di negara tersebut akan dapat tergantikan menjadi kesejahteraan. Bagaimanapun, dalam perkembangannya, pendidikan di Indonesia senantiasa harus menghadapi beberapa masalah di setiap tahapnya. Masalahmasalah tersebut hanya dapat diselesaikan dengan partisipasi dari semua pihak yang terkait di dalam sistem pendidikan, seperti orangtua, guru-guru, kepala sekolah, masyarakat, dan juga peserta didik itu sendiri. Pada fase input, orangtua memiliki kontribusi besar dalam memperkenalkan nilai-nilai baik kepada anak-anak mereka. Orangtua bertanggung jawab penuh untuk mendidik anak-anak mereka dengan nilai-nilai kepemimpinan, sehingga mereka mempunyai bekal yang cukup untuk menjadi cikal bakal pemimpin ketika mereka mulai memasuki institusi formal, seperti sekolah. Pada fase proses, orangtua bekerjasama dengan para guru dan kepala sekolah untuk memberikan penguatan kepada peserta didik dalam menerapkan nilai-nilai kepempinan yang baik melalui budaya organisasi di sekolah. Terakhir, pada tahap output, peserta didik harus menghadapi begitu banyak tantangan di dunia nyata, di luar sekolah. Peserta didik yang sudah melalui tahap-tahap sebelumnya di sekolah dengan budaya organisasi yang mengajarkan dan membiasakan nilai-nilai baik dalam hidupnya, maka akan tumbuh menjadi pemimpin yang hebat untuk negara ini (Megawanti, 2012).

Pasal 1 UU SISDIKNAS no. 20 tahun 2003 disebutkan bahwa Sistem Pendidikan Nasional adalah keseluruhan komponen pendidikan yang saling terkait secara terpadu untuk mencapai tujuan pendidikan nasional. Berangkat dari bunyi pasal ini dapat diketahui bahwa pendidikan adalah sistem yang merupakan suatu totalitas struktur yang terdiri dari komponen yang saling terkait dan secara bersama menuju kepada tercapainya tujuan (Soetarno, 2003: 2). Adapun komponen-komponen dalam pendidikan nasional antara lain adalah lingkungan, sarana-prasarana, sumberdaya, dan masyarakat. Komponen-komponen tersebut bekerja secara bersama-sama, saling terkait dan mendukung dalam mencapai tujuan pendidikan (Munirah, 2015).

Landasan hukum yang melandasi terlaksananya pendidikan adalah seperti pembukaan Undang-Undang Dasar 1945 pada alinea keempat, dengan demikian menjadi jelas bahwa mendidik adalah mencerdaskan kehidupan bangsa. Bangsa yang cerdaskan kehidupan bangsa. "Bangsa yang cerdas adalah yang dapat menggunakan asal budinya (multipleintelligence) di dalam menghadapi kehidupan berdasarkan pertimbangan moral" (tilaar dalam pengantar pendidikan 2013:41). Hal ini memiliki arti yang sangat luas, kecerdasan tidak terbatas pada kecerdasan intelektual saja, melainkan juga kecerdasan afektif. Maka pendidikan wajib mengembangkan multi inteligensi, dalam kaitannya dengan hal tersebut guru diharapkan mampu memberikan inovasi dalam pembelajaran.

Upaya meningkatkan hasil belajar siswa, perlu dikembangkan suatu pembelajaran yang mampu menumbuhkan minat siswa. Sehingga dapat meningkatkan hasil belajar siswa. Adanya kreaktivitas dalam penggunaan model dan media pembelajaran, diharapkan prestasi sekolahpun dapat meningkat karena dengan perencanaan yang seksama, kebutuhan untuk seluruh siswa dapat terpenuhi. Sehingga guru harus berlatih secara khusus dan intensif untuk bisa mengelola proses belajar supaya kegiatan belajar mengajar berlangsung dengan baik dan mudah diterima oleh siswa. Menurut pengamatan yang saya lakukan di SD negeri Kembangsari 01 di saat mengajar pramuka siswa menunjukan bahwa anak usia sekolah dasar yang lebih percaya diri jika dirinya berada di suatu kelompok tertentu dibandingkan mereka sendirian, dan anak usia sekolah dasar masih suka bermain serta berkompetisi sehingga saya tertarik mengambil penelitian mengenai hal tersebut dengan judul "Pengaruh model kooperatif tipe team game tournament berbantu media ledusa tema 3 kelas IV SDN Kembangsari 01 Semarang".

Masalah yang diangkat dalam penelitian ini adalah:"Apakah ada pengaruh yang signifikan model kooperatif tipe team game tournament berbantu media ledusa pada hasil belajar siswa SDN Kembangsari 01 kelas IV?". Tujuan yang ingin dicapai penelitian ini yaitu 
untuk mengetahui pengaruh model pembelajaran kooperatif tipe team game tournament berbantu media ledusa tema 3 kelas IV SDN Kembangsari 01.

\section{Metode}

Penelitian Dalam penelitian ini, metode penelitian yang digunakan adalah motode penelitian pre-eksperimental designs. Desain yang digunakan pada penelitian adalah one-group pretest-posttest design. Di dalam penelitian ini terdapat satu kelompok yang diteliti, sebelum melakukan perlakuan dengan model kooperatif tipe teams game tournament terdapat pretest . Dengan demikian peneliti dapat mengetahui keadaan sebelum diberi perlakuan menggunakan model kooperatif tipe teams game tournament berbantu media ledusa, setelah siswa diberi perlakuan dengan model kooperatif tipe teams game tournament berbantu media ledusa dilakukan posttest untuk mengetahui hasil belajar siswa.

Tabel 1. Desain Pre-eksperimental designs One-grup pretest-posttest design

\begin{tabular}{lll}
\hline $\mathrm{O}_{1}$ & $\mathrm{X}$ & $\mathrm{O}_{2}$ \\
\hline
\end{tabular}

Keterangan:

$\mathrm{O}_{1} \quad$ : Nilai tes awal

$\mathrm{X} \quad$ : Perlakuan

$\mathrm{O}_{2} \quad$ : Nilai tes akhir

Penelitian ini hanya menggunakan satu kelas saja dimana penelitian ini dapat menguji pengaruh model kooperatif tipe TGT berbantu media ledusa, dengan membandingkan hasil siswa sebelum diberi perlakuan dan sesudah diberi perlakuan.

\section{Hasil dan Pembahasan}

1. Langkah-Langkah Penelitian

Langkah-langkah penelitian yang telah dilakukan peneliti dalam melaksanakan penelitian agar penelitian dapat terlaksana dengan baik dan lancar. Langkah yang telah dilakukan peneliti dalam penelitian meliputi:

a. Koordinasi dan perijinan

Langkah awal yang diperlukan dalam persiapan penelitian adalah masalah koordinasi dan perijinan kepada pihak sekolah yang bersangkutan yaitu SDN Kembangsari 01 dan SDN Kembangsari 02 Semarang. Peneliti melakukan koordinasi untuk mengetahui diperbolehkan atau tidak melakukan penelitian di sekolah tersebut.

b. Menentukan sekolah uji coba

Peneliti menentukan sekolah uji coba dengan memperhatikan karakteristik siswa yang sama dengan siwa yang akan diteliti, yaitu di SDN Kembangsari 02 Semarang kelas IV dan tidak digunakan sebagai sampel.

c. Melakukan uji coba instrument

Soal uji coba diberikan kepada kelas uji coba dan hasil dari tes uji coba kemudian dianalisis untuk mengetahui validitas, reliabilitas, daya pembeda, dan taraf kesukaran. Selanjutnya memilih soal-soal yang memenuhi kriteria untuk dijadikan tes evaluasi. Soal-soal yang dipilih tersebut kemudian diberikan kepada kelas eksperimen pada awal dan akhir pertemuan sebagai evaluasi (pre-test dan post-test) untuk mendapatkan data awal dan akhir berupa nilai prestasi belajar siswa.

d. Menentukan sampel penelitian

Menentukan sampel penelitian dari siswa kelas IV SDN Kembangsari 01 Semarang tahun ajaran 2018/2019 dilakukan dengan teknik non probability sampling dengan jenis sampling jenuh." Karena jumlah populasi relatif kecil sehingga semua populasi menjadi sempel.

e. Menganalisis data awal

Sebelum dilakukan perlakuan, terlebih dahulu peneliti melakukan pre-test kelas IV ajaran 2018/2019 untuk mengetahui data awal. Selanjutnya data awal tersebut dianalisis untuk dihitung normalitasnya, normalitas dilakukan untuk mengetahui apakah sampel berasal dari populasi yang berdistribusi normal atau tidak. Kemudian dilanjutkan dengan uji beda (uji paire samples $t$-test), uji beda dilakukan untuk mengetahui ada atau tidaknya perbedaan hasil belajar siswa setelah diberi perlakuan. 


\section{Analisis Uji Coba Intrumen}

Untuk memperoleh instrumen penelitian berupa tes yang baik, maka tes tersebut perlu diuji cobakan terlebih dahulu sebelum diberikan kepada kelas eksperimen. Instrumen tes yang baik harus memenuhi validitas, reliabilitas, taraf kesukaran, dan daya pembeda yang baik. Adapun banyak item soal yang diuji cobakan sebanyak 30 soal pilihan ganda. Analisis hasil uji coba soal dipaparkan sebagai berikut:

a. Validitas

Setelah diujicobakan pada siswa diluar sampel, intrumen tes tersebut diuji validitasnya dengan menggunakan rumus product moment sebagai berikut:

$r_{x y}=$ Kemudian hasil $r_{x y}$ dikonsultasikan dengan harga $r$ product moment dengan taraf signifikan 0,05 atau $5 \%$ dan $N=24$ yaitu $r_{\text {tabel }}=0,43$. Jika $r_{x y}>0,43$ maka soal dikatakan valid dan sebaliknya $r_{x y} 0,43$ maka soal dikatakan tidak valid.

Hasil tes dari 30 soal didapat 20 butir soal yang valid yaitu soal nomor 1, 3, 5, 6, 7, 8, 10, $11,13,14,15,18,19,20,23,24,25,26,29,30$. Sedangkan soal yang tidak valid ada 10 yaitu soal nomor $2,4,9,12,16,17,21,22,27,28$.

Tabel 2. Hasil Uji Validitas Butir Soal Uji Coba

\begin{tabular}{ccccc}
\hline No & Nilai Interval $r_{\text {hitung }}$ & frekuensi & $r_{\text {tabel }}$ & Keterangan \\
\hline 1 & $-0,3-0,14$ & 10 & 0,43 & Tidak Valid \\
2 & $0,48-0,77$ & 20 & 0,43 & Valid \\
& Jumlah & 30 & & \\
\hline
\end{tabular}

b. Reliabilitas

Soal yang diujikan berupa pilihan ganda, maka untuk mendapatkan indeks reliabilitas Kuder Richardson 20 (K-R20) yaitu:

dengan klasifikasi reliabilitas adalah sebagai berikut:

$0,800<r_{11} 1,00=$ reliabilitas sangat tinggi

$0,600 \mathrm{r}_{11} 0,800=$ reliabilitas tinggi

$0,400 \mathrm{r}_{11} 0,600=$ reliabilitas cukup

$0,200 \mathrm{r}_{11} 0,400=$ reliabilitas rendah

$0,000 r_{11} 0,200=$ reliabilitas sangat rendah

Dengan taraf signifikan 0,05 atau $5 \%$ dan $\mathrm{N}=24$ diperoleh nilai $r_{\text {tabel }}=0,43$ dari lampiran

5 , serta perhitungan pada lampiran 5 diperoleh $r_{\text {hitung }}=0,75$. Karena $r_{\text {hitung }}=0,75>r_{\text {tabel }}=0,43$ dapat disimpulkan instrument tes reliabel dengan tingkat reliabilitas klasifikasi tinggi.

c. Taraf kesukaran

Cara menghitung taraf kesukaran soal bentuk pilihan ganda adalah sebagai berikut:

1) Menghitung tingkat kesukaran soal bentuk pilihan ganda adalah sebagai berikut:

Tingkat kesukaran $=$

2) Membandingkan tingkat kesukaran dengan kriteria berikut:

$0,00<\mathrm{P} 0,30$ adalah soal sukar

$0,00<\mathrm{P} 0,70$ adalah soal sedang

$0,00<\mathrm{P} 1,00$ adalah soal yang mudah

Dari hasil perhitungan taraf kesukaran soal diperoleh data dua puluh satu soal mudah dan Sembilan soal sedang, soal yang mudah terdapat pada nomor 1, 2, 3, 4, 5, 6, 7, 8, 10, 12 , $13,18,19,20,23,24,25,26,27,29,30$. Sedangkan soal yang sedang terdapat pada nomor 9 , $11,14,15,16,17,21,22,28$.

\section{d. Daya pembeda}

Analisis daya pembeda dilakukan untuk mengetahui kemampuan soal dalam membedakan siswa yang berkemampuan tinggi dan siswa berkemampuan rendah. Dari hasil perhitungan diperoleh terdapat 10 siwa kelompok atas dan 11 siswa kelompok bawah, taraf signifikan $5 \%$. soal dibagi menjadi beberapa kriteria soal jelek, cukup, baik dan baik sekali,dari 30 soal yang dinyatakan jelek ada 15 soal yaitu nomor 1, 2, 3, 6, 9, 10, 13, 16, 17, 18, 21, 22, $27,28,29$, lalu soal dengan kriteria cukup ada 8 soal yaitu pada nomor $5,8,12,19,20,25,26$, 30 , kemudian soal dengan kriteria baik ada 6 soal yang terdapat pada nomor $4,7,11,15,23$, 24 , dan soal yang dinyatakan baik sekali terdapat pada nomor 14 .Soal yang akan diajukan 
sebagai soal tes untuk mengambil data ditentukan dengan mempertimbangkan validitas, reliabilitas, taraf kesukaran dan daya pembeda soal.

3. Analisis Data Awal

Analisis data awal dilakukan untuk memperoleh sampel yang tidak berbeda secara signifikan. Data yang dianalisis hasil pretest siswa kelas VI semester gasal SDN Kembangsari 01 Semarang tahun pelajaran 2018/2019. Adapun analisis data awal yaitu uji normalitas.

Uji normalitas digunakan untuk mengetahui untuk mengetahui sampel berasal dari populasi yang berdistribusi normal atau tidak. Uji yang digunakan adalah uji Lilliefors. Hipotesis pada uji normalitas yaitu:

$\mathrm{H}_{0} \quad$ : Sampel berasal dari populasi yang berdistribusi normal

$\mathrm{H}_{1} \quad$ : Sampel tidak berasal dari populasi yang berdistribusi normal

Tabel 3. Uji Normalitas Awal

\begin{tabular}{ccccccc}
\hline$\Sigma$ & rata-rata & $\mathrm{S}$ & $\mathrm{s}^{\wedge} 2$ & $\mathrm{~L}_{\text {tabel }}$ & $\mathrm{L}_{\mathrm{o}}$ & Kriteria \\
\hline 1720 & 71,6667 & 12,3945 & 153,623 & 0.18085 & 0,12568 & Normal \\
\hline
\end{tabular}

Berdasarkan Tabel 3 diatas, nilai $L_{0}=0,12568$ dan $L_{\text {tabel }} 0,12568$ hal ini berarti $L_{o}<$ $L_{\text {tabel }}$ sehingga dapat disimpulkan $\mathrm{H}_{0}$ diterima. Artinya sampel berasal dari populasi berdistribusi normal.

\section{Analisis Data Akhir}

Analisis data akhir dilakukan untuk melakukan uji hipotesis setelah dilakukan perlakuan. Data yang dianalisis adalah nilai tes akhir siswa (post-tes).

a. Uji normalitas

Uji normalitas digunakan untuk mengetahui sampel berasal dari populasi yang berditribusi normal atau tidak. Uji yang digunakan adalah uji Lilliefors. Hipotesis pada uji normalitas yaitu:

$\mathrm{H}_{\mathrm{o}} \quad$ : Sampel berasal dari populasi yang berdistribusi normal

$\mathrm{H}_{1} \quad$ : Sampel berasal dari populasi yang berditribusi normal

Tabel 4. Uji Normalitas Akhir

\begin{tabular}{ccccccc}
\hline$\Sigma$ & rata-rata & $\mathrm{S}$ & $\mathrm{s}^{\wedge} 2$ & $\mathrm{~L}_{\text {tabel }}$ & $\mathrm{L}_{\circ}$ & Kriteria \\
\hline 1965 & 81,875 & 9,87008 & 97,4185 & 0,18085 & 0,17362 & Normal \\
\hline
\end{tabular}

Berdasarkan Tabel 4 diatas, nilai $L_{o}$ sebesar 0,17362 sedangkan $L_{\text {tabel }}$ sebesar 0,18085 sehingga diperoleh $L_{o}=0,17362<L_{\text {tabel }}=0,18085$. Hal ini berarti $H_{o}$ diterima, jadi sampel berasal dari populasi berdistribusi normal.

b. Uji beda

Uji beda ( uji paire samples t-test) setelah mengumpulkan data dilanjutkan menganalisis data-data yang sudah diambil dengan uji t, uji t bertujuan untuk mengetahui perbedaan sebelum diberi perlakuan dan sesudah siswa diberi perlakuan, adapun hipotesis $\mathrm{H}_{1}$ : $\mathrm{H}_{0}$ : . Statistik yang digunakan:Dengan

Kriteria pengujian adalah $\mathrm{H}_{0}$ diterima jika $\mathrm{t}<\mathrm{t}_{\text {tabel }}$ dan ditolak jika $\mathrm{t}_{\text {hitung }}<\mathrm{t}_{\text {tabel }}$ maka $\mathrm{Ho}$ ditolak. Dari hasil perhitungan di dapat nilai $t=-3,15637<\mathrm{t}_{\text {tabel }}=2,06$, dapat disimpulkan bahwa $\mathrm{H}_{\mathrm{o}}$ ditolak dan $\mathrm{H}_{1}$ diterima artinya rata-rata hasil post-test lebih baik daripada pre-test. Hal ini dapat dilihat dari diagram berikut: 


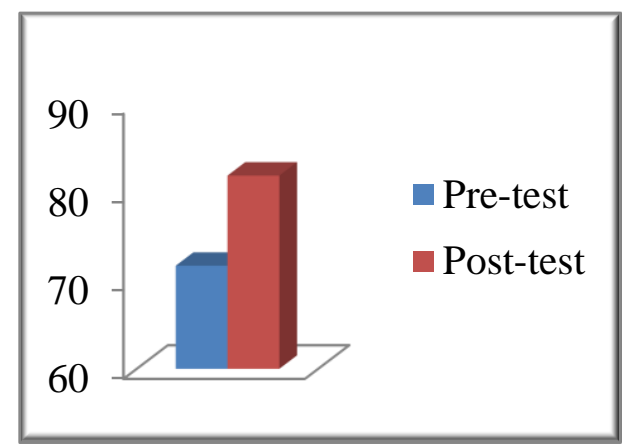

Gambar 1. Diagram batang nilai rata-rata pre-test dan post-test

Tujuan dalam penelitian ini adalah untuk melihat mengenai pengaruh model kooperatif tipe team game tournament berbantu media ledusa tema 3 peduli terhadap makhluk hidup kelas 4 SDN Kembangsari 01 Semarang.

\section{Data Awal}

Sebelum dilakukan perlakuan, terlebih dahulu dilakukan analisis awal. Analisis awal menggunakan nilai pre-test sebelum siswa diberi perlakuan menggunakan model kooperatif tipe team game tournament berbantu media ledusa pada tema 3 peduli terhadap makhluk hidup. Dari analisis data awal, didapat bahwa dengan uji normalitas ternyata kelas untuk penelitian berasal dari populasi yang berdistribusi normal.

Setelah dilakukan pembelajaran tema 3 dengan menggunakan model kooperatif tipe team game tournament berbantu media ledusa, kemudian dilakukan post-test untuk mengetahui hasil belajar siswa sebagai data akhir. Soal tes yang diberikan telah memenuhi tahap uji coba di kelas 4 SDN Kembangsari 02 sehingga soal tersebut memenuhi syarat sebagai soal post-test (instrument penelitian), yaitu valid, reliable, signifikan, dan memiliki taraf kesukaran.

\section{Data Akhir}

Data akhir yang berupa nilai post-test pada tema 3 kelas $\mathrm{VI}$ dianalisis menggunakan uji normalitas dan uji beda (uji paire samples t-test).

Uji normalitas yang dilakukan pada kelas eksperimen berdasarkan alalisis didapat keputusan $\mathrm{H}_{0}$ diterima, artinya kelas eksperimen berasal dari populasi berditribusi normal.

Kemudian hasil perhitungan untuk membandingkan hasil belajar siswa yaitu berdasarkan hasil analisis. Untuk uji beda (uji paire samples t-test) didapat nilai $t=-3,15637$. Karena $t=-$ $3,15637<t_{\text {tabel }} 2,06$ dapat disimpulkan bahwa $\mathrm{H}_{0}$ ditolak dan $\mathrm{H}_{1}$ diterima artinya rata-rata hasil belajar siswa lebih baik daripada sebelumnya. Hal ini diperkuat dengan penelitian yang dilakukan oleh Abdus Salam, Anwar Hosain dan Shahidur Rahman yang berjudul "Teams game tournaments (TGT) cooperative technique for learning mathematics in secondary schools in Bangladesh". Penelitian ini membahas pengaruh permainan terhadap kinerja dan sikap siswa terhadap matematika kelas VIII. Penelitian ini dilakukan dengan menerapkan Teknik TGT untuk kelompok eksperimen dan pendekatan ceramah berbasis tipikal untuk kelompok kontrol Tes prestasi yang sama digunakan seperti pada tes pra-test dan post-test, inventarisasi sikap terhadap matematika diterapkan untuk tes pra-test dan post-test. Pada kelompok percobaan dan control TGT, skala sikap pada permainan komputer diperuntukan kelompok eksperimen TGT, wawancara semi-terstruktur untuk guru dan pedoman FGD untuk siswa ditetapkan untuk melayani tujuan penelitian. Setelah tiga minggu melakukan intervensi, ditemukan bahwa kelompok eksperimen TGT siswa telah mencapai hasil belajar yang signifikan daripada kelompok kontrol berbasis kuliah siswa. Sifat terhadap matematika berbeda dengan tingkat positif tertentu pada TGT kelompok eksperimen.

Dari penjelasan diatas dapat disimpulkan bahwa telah terbukti penggunaan model kooperatif tipe team game tournament berbantu media ledusa berpengaruh terhadap pembelajaran tema 3 peduli terhadap makhluk hidup pada kelas VI SDN Kembangsari 01 Semarang. 


\section{Simpulan dan Saran}

Berdasarkan rumusan masalah, hasil penelitian, dan pembahasan yang telah dipaparkan pada bab sebelumnya, peneliti dapat menarik simpulan bahwa model pembelajaran kooperatif tipe team game tournament berbantu media ledusa tema 3 kelas IV SDN ada pengaruh yang signifikan, hal ini terlihat pada hasil rata-rata sebelum dan sesudah diberi perlakuan. Rata-rata sebelum diberi perlakuan adalah 71,67 dan rata-rata setelah diberi perlakuan adalah 81,87 karena $\mathrm{H}_{1}$ diterima maka Ada pengaruh yang signifikan penggunaan model pembelajaran kooperatif tipe team game tournament berbantu media ledusa tema 3 kelas 4 SDN Kembangsari 01 yaitu sebagai berikut: 1) dalam proses pembelajaran dengan model pembelajaran kooperatif tipe team game tournament berbantu media ledusa dapat digunakan sebagai alternatif dalam proses pembelajaran karena berdasarkan penelitian model pembelajaran kooperatif tipe team game tournament berbantu media ledusa meningkatkan hasil belajar siswa, 2) guru hendaknya tidak menggunakan model pembelajaran yang monoton untuk menghindari kejenuhan, 3) guru hendaknya mencoba menggunakan media yang menarik dan sesuai dengan materi yang hendak akan diajarkan

Adapun keterbatasan peneliti dalam penelitian sebagai berikut: 1) Model pembelajaran kooperatif tipe team game tournament berbantu media ledusa perlu adanya penelitian lebih lanjut pada pokok tema yang berbeda, 2) Membuat dua arena atau lebih untuk mempercepat proses pembelajaran sehingga semua siswa dapat mencoba dan waktu yang digunakan juga tidak terlalu lama, 3) Sistem poin perlu ditampilkan dengan jelas agar semua siswa dapat melihatnya.

\section{Daftar Pustaka}

Anwar, Desi. 2001. Kamus Lengkap Bahasa Indonesia. Surabaya: Karya Abaditama.

Arikunto. 2010. Prosedur Penelitian: Suatu Pendekatan Praktik. Jakarta: Bumi Aksara.

Arikunto. 2006. Dasar-Dasar Evaluasi Pendidikan (Edisi Revisi). Jakarta: Bumi Aksara.

Arikunto. 2012. Dasar-Dasar Evaluasi Pendidikan. Jakarta: Bumi Aksara.

Buku temati terpadu kurikulum 2013 revisi 2017.Jakarta: Pusat kurikulum dan perbukuan kementrian pendidikan dan kebudayaan

Iru dan Safiun. 2012. Analisis Penerapan Pendekatan, Metode, Strategi, dan Model Model Pembelajaran. DIY: Multi Presindo.

Jimmy dan Larry. 2001."Dadu (permainan)". https://id.m.wikipedia.org/Dadu (permainan). Ensiklopedia. Diakses 5 Maret 2018.

Megawanti, Priarti . 2012. Meretas Permasalahan Pendidikan Di Indonesia . Jurnal Formatif 2(3): 227-234 ISSN: 2088-351X

Munirah. 2015. Sistem Pendidikan Di Indonesia: Antara Keinginan Dan Realita . Jurnal Auladuna, Vol. 2 No. 2 Desember 2015: 233-245 238

Purwanto. 2014. Evaluasi Hasil Belajar. Yogyakarta: Pustaka Pelajar

Ratumanan. 2015. Inovasi Pembelajaran. Yogyakata: Ombak.

Salam, dkk. 2015. "Teams Game Tournaments (TGT) Cooperative Technique for Learning Matematics in Secondary Schools in Bangladesh". Jurnal. Diakses 28 November 2017 pukul 16.35 wib. https://files.eric.ed.gov/fulltext/EJ1111784.pdf

Saputra, dkk. 2015. Dasar-Dasar Pendidikan IPA SD. Semarang: Jurusan PGSD Universitas.

Saputra, dkk. 2016. Suplemen Pendidikan IPA SD 2. Semarang: Jurusan PGSD Universitas. 
JP2, Vol 2 No 3, Tahun 2019

p-ISSN : 2614-3909 e-ISSN : 2614-3895

Setianingsih, dkk. 2017. Perkembangan Peserta Didik. Semarang: Jurusan PGSD FIP Universitas.

Slameto. 2010. Belajar dan Factor-Faktor yang Mempengaruhi. Jakarta: PT Rineka Cipta.

Slavin, R. E. 2005. Cooperative Learning. Bandung: Nusa Media.

Soegeng, A.Y. 2017. Filsafat Pendidikan. Yogyakarta: Maknum Pustaka Utama.

Sudharto, dkk.2013. Pengantar IImu Pendidikan. Semarang: Ikip PGRIPress.

Sugiyono. 2016. Metode Penelitian Pendidikan. Bandung: Alfabeta.

Zulkarnain, Rizal. 2016. "Pengaruh Model Teams Games Tournament Melalui Permainan Sudamanda terhadap Hasil Belajar Siswa pada Materi Jenis-Jenis Pekerjaan Kelas III". Skripsi. Semarang: Universitas PGRI. 